\title{
The Cost of Maintenance Processes in Plant Cells
}

\author{
F. W. T. PENNING DE VRIES \\ Department of Theoretical Production Ecology, Agricultural University, Wageningen, \\ The Netherlands
}

Received: 1 November 1973, and revised 14 April 1974

\begin{abstract}
The most important maintenance processes in plants are protein turnover and active transport processes to maintain certain ion concentrations in the cells. In this paper an attempt is made to calculate the total energy cost of these processes from what is known about their specific costs and what has been observed about their rates. Because of insufficient reliable data about rates of individual maintenance processes, only approximate values can be obtained.

The average turnover rate of leaf proteins may be about $100 \mathrm{mg}$ protein per $\mathrm{g}$ proteins per day at normal temperature in leaves assimilating at moderate light intensities. This process consumes $28-53 \mathrm{mg}$ glucose per g protein per day, which equals $7-13 \mathrm{mg}$ glucose per $\mathrm{g}$ dry weight per day in leaves. It is likely that the rates of protein turnover and of $\mathrm{CO}_{2}$-assimilation are related. The cost of maintaining ion concentrations is estimated to be about $6-10 \mathrm{mg}$ glucose per $\mathrm{g}$ dry weight per day in leaves. The sum of these figures is lower than is indicated by measurements of maintenance respiration. One reason for the underestimation may be that the protein turnover rates used in the calculations apply to plants with lower photosynthetic rates than the plants in which the maintenance respiration was measured. Effects of water stress and salinity, temperature and other environmental factors on the rate of maintenance processes are discussed.

The consumption of assimilates for maintenance of plant cells is a significant, negative factor in plant productivity. A better understanding of the maintenance processes may give a clue how to manipulate plant characteristics or the environment to reduce the amount of assimilates consumed in these processes. It is suggested that reduction in protein turnover rates may be one such manipulation.
\end{abstract}

\section{INTRODUCTION}

All living cells expend energy for maintenance purposes. A few attempts have been made to establish experimentally the intensity of this energy consumption in plants, which can be appreciable. In so far as the author is aware no work has been published on the calculation of maintenance cost for plant cells from basic data. This paper presents a preliminary calculation of the energy and substrate requirement for the maintenance of cells of higher plants, which is largely based on information from the literature on the nature and rate of the underlying processes. Present knowledge only allows a first estimate of maintenance cost, but indicates the main areas for further research.

The term 'maintenance' includes the processes which maintain cellular structures and gradients of ions and metabolites, and also the processes of physiological adaptation that maintain cells as active units in a changing environment. Formation of new enzymes at the expense of others and salt accumulation in some stress conditions are examples of such adaptations. Hence, maintenance is not as conservative a process as its name suggests. When using the concepts 'maintenance' and 'growth' it must be realized that these terms always imply a certain level of complexity: an ecologist may consider growth of an organism as one of the processes maintaining population size, while maintenance of the number of erythrocytes is a growth process to the histologist. This study concentrates on maintenance processes in cells. Some redistribution processes in plants can be regarded as maintenance processes of the organism, but these are not considered in this paper. 'Maintenance respiration' refers to the $\mathrm{CO}_{2}$ that results from protein breakdown, plus 
the $\mathrm{CO}_{2}$ produced in respiratory processes that provide energy for the maintenance processes.

In calculating maintenance cost information is needed about the rates of processes, their specific costs and the efficiency of energy production. Calculation of rates of individual maintenance processes from more basic data is impossible as yet, since so little is known about mechanisms and regulation of these processes. Thus, direct measurements of such rates are indispensable. To find the specific cost of maintenance processes, the cost of maintaining concentrations of ions and metabolites, the biochemical cost of breakdown and resynthesis of molecules and the use to be made of breakdown products will be considered. Beevers (1961) collected evidence that in plants under normal conditions the efficiency of energy utilization from organic substrates, measured as the $\mathrm{P}: \mathrm{O}$ ratio of $\mathrm{NADH}_{2}$ oxidation, is close to the maximum value of 3, as in animals (Lehninger, 1970). Lower P:O ratios have often been observed, but these may be attributed, at least partly, to the procedure by which mitochondria were isolated (Romani and Ozelkok, 1973). In the calculations below it will be assumed that mitochondrial phosphorylation in higher plants in non-stressed conditions is maximally efficient. For bacteria there is evidence that the P:O ratio may be considerably less than 3 (cf. Stouthamer, 1973; Stouthamer and Bettenhausen, 1973). The substrate demand for maintenance processes increases inversely with this efficiency. Since glucose or other monosaccharides are the first substrates consumed for energy production, maintenance cost will be expressed in $\mathrm{mg}$ glucose per $\mathrm{g}$ dry matter per day. Because the ratio of moles $\mathrm{CO}_{2}$ produced to moles $\mathrm{O}_{2}$ consumed in mature organs under normal conditions is mostly about unity (James, 1953) complete oxidation of glucose will be assumed.

\section{RATES AND COST OF MAINTENANCE PROCESSES UNDER STANDARD CONDITIONS}

\section{Maintenance of molecular structures}

Breakdown and resynthesis of nitrogenous compounds. Only a short account of the present state of research on protein turnover will be given; for details the reader is referred to reviews by Glasziou (1969), Schimke (1969), Schimke and Doyle (1970), Pine (1972) and Siekevitz (1972). In spite of much research in this field it is still difficult to construct more than a general picture of protein turnover in different organisms and in plant organs particularly.

Protein breakdown is mainly an enzymic process (Travis, Jordan, and Huffaker, 1969; Pine, 1972), but no energy seems to be required for peptide bond cleavage (Pine, 1972). Once degradation starts enzyme activity decreases exponentially. Schimke (1969) and Pine (1972) suggested that, as a general rule, enzymes may be automatically stabilized against proteolysis when interacting with their substrates. Both enzyme synthesis and breakdown can be regulated (Schimke and Doyle, 1970; Trewavas, 1972), but the control mechanism in eukaryotes is still largely unexplained. Long-term changes of enzyme activity usually involve breakdown or de novo synthesis (Beevers and Hageman, 1969; Travis et al., 1969; Zucker, 1972; Oaks, Wallace, and Stevens, 1972).

Information collected by Pine (1972) indicates that the bulk of bacterial protein (70 per cent) is stable. A small fraction (1-7 per cent) has a turnover rate constant (abbreviated to turnover rate) of $17-70 \mathrm{~g}$ protein per $\mathrm{g}$ protein per day (abbreviated to $17-70 \mathrm{day}^{-1}$; this represents the relative rate of decrease when exponential decay occurs). Other proteirs are stable in growing bacteria, but have a turnover rate of about $2.4 \mathrm{day}^{-1}$ in non-growing cells starved of nitrogen. Overall protein turnover amounts to $0 \cdot 6-0 \cdot 7$ day $^{-1}$ in growing, and to $1 \cdot 2-1 \cdot 4 \mathrm{day}^{-1}$ in non-growing bacteria.

The literature about plant protein turnover is limited and is confined mainly to leaves. Turnover rates of total leaf protein were reported to be about $0 \cdot 10$ day $^{-1}$ in tobacco leaves 
(Holmsen and Koch, 1964), measured as the rate of incorporation of ${ }^{14} \mathrm{CO}_{2}$ into proteins. Since protein turnover is possible without incorporation of ${ }^{14} \mathrm{CO}_{2}$ into amino acids this method provides a minimum value. Racusen and Foote (1962) determined the rate of loss of labelled protein-serine and protein-glycine from bean leaf discs and obtained a turnover rate of about $0 \cdot 22$ day $^{-1}$. Hellebust and Bidwell (1964b) reported protein turnover rate of $0.11 \mathrm{day}^{-1}$ in rapidly growing wheat leaves and of $0.04 \mathrm{day}^{-1}$ in expanding tobacco leaves, while that of non-growing wheat leaves was $0.06 \mathrm{day}^{-1}$, and a value of almost zero was obtained for non-growing tobacco leaves. These workers measured the rate of loss of ${ }^{14} \mathrm{CO}_{2}$ from previously labelled proteins, which in fact reflects amino acid turnover rather than protein turnover. The decrease in turnover rate with cessation of growth was ascribed to completion of cell differentiation. The rate of protein breakdown in growing Lemna minor under normal conditions is $0.096 \pm 0.005$ day $^{-1}$ (Trewavas, 1972). Protein turnover was $0.2-0.5 \mathrm{day}^{-1}$ in Chlorella cells adapting to a glucose substrate. In these studies relatively rapid labelling or loss of label from a small fraction was not detected. The previously labelled soluble protein fraction minus ribulose 1,5 diphosphate carboxydismutase (RuDPCase) of barley leaves, comprising about half of the total leaf proteins, showed a loss of ${ }^{14} \mathrm{CO}_{2}$ of $0 \cdot 14$ day $^{-1}$ at a constant light intensity of about $30 \mathrm{~W} \mathrm{~m}^{-2}$ (Peterson, Kleinkopf, and Huffaker, 1973). Such protein turnover rates allow adaptation of the enzyme system to environmental changes in 2-4 days, which is the correct order of magnitude.

More information about protein turnover can be found on the level of individual enzymes. However, quantities of enzymes are seldom reported, which is a great handicap in using these data. Some enzyme turnover rates have been collected in Table 1. The high turnover rate of vacuolar invertase in sugar cane (Table 1) was questioned by Trewavas (1972) because of the method used in its determination. Degradation and resynthesis of RuDPCase in expanded barley leaves was investigated by Peterson et al. (1973). In darkness

TABLE 1. Some enzyme and RNA turnover rates in various plant tissues under normal conditions

\begin{tabular}{|c|c|c|}
\hline Enzyme and tissue & $\begin{array}{l}\text { Turnover rate } \\
\left(\text { day }^{-1}\right)\end{array}$ & Reference \\
\hline $\mathrm{NO}_{3}^{-}$-reductase; maize seedlings & $3 \cdot 6$ & Glasziou, 1969 \\
\hline \multicolumn{3}{|l|}{$\mathrm{NO}_{3}^{-}$-reductase; maize roots (degradation rate in a } \\
\hline $\mathrm{NO}_{3}^{-}$-free medium) & $4 \cdot 1$ & Oaks et al., 1972 \\
\hline Hexose uptake system; Chlorella sp. & $4 \cdot 1$ & Tanner et al., 1970 \\
\hline \multicolumn{3}{|l|}{ Phenylalanine ammonia lysase; mustard seedlings } \\
\hline (degradation rate in darkness) & $2 \cdot 9$ & Glasziou, 1969 \\
\hline Isocitrate lyase; Chlorella sp. (degradation rate in darkness) & $2 \cdot 2$ & Johnet al., 1970 \\
\hline Invertase; sugar cane & $4 \cdot 8$ & Glasziou, 1969 \\
\hline Invertase; artichoke and carrot & $1 \cdot 5$ & Trewavas, 1972 \\
\hline Invertase; sguar beet and red beet & $0 \cdot 7$ & Trewavas, 1972 \\
\hline Cellulose; pea epicotyl & 0.6 & Glasziou, 1969 \\
\hline \multicolumn{3}{|l|}{ RuDPCase, expanded barley leaves } \\
\hline (degradation rate in darkness) & $0 \cdot 06-0.38$ & Peterson et al., 1973 \\
\hline (synthesis rate in light) & $0 \cdot 12-0.55$ & Peterson et al., 1973 \\
\hline Isocitrate lyase, melon & $0 \cdot 36$ & Glasziou, 1969 \\
\hline Malate synthetase, melon & $0 \cdot 36$ & Glasziou, 1969 \\
\hline RNAase & 0 & Glasziou, 1969 \\
\hline Peroxidase & 0 & Glasziou, 1969 \\
\hline $\mathrm{NO}_{3}^{-}$-reductase mRNA, maize roots & $48 \cdot 0$ & Oaks et al., 1972 \\
\hline mRNA, potato tuber & $7 \cdot 0$ & Glasziou, 1969 \\
\hline Peroxidase mRNA, sugar cane & $7 \cdot 0$ & Glasziou, 1699 \\
\hline Cytoplasma rRNA, Lemna minor & $0 \cdot 17$ & Trewavas, 1970 \\
\hline Chloroplast rRNA, Lemna minor & 0.05 & Trewavas, 1970 \\
\hline
\end{tabular}


the rate of degradation was about 0.06 day $^{-1}$ initially, increasing to 0.38 day $^{-1}$ after $30 \mathrm{~h}$, and subsequently it decreased. When the plants were returned to the light RuDPCase was resynthesized at rates of 0.12 day $^{-1}$ initially and 0.55 day $^{-1}$ after $20 \mathrm{~h}$. Degradation of RuDPCase in constant light was not detected.

As in bacteria and yeasts (Mandelstam, 1960), DNA turnover in full-grown leaves is very slow (Dyer and Osborne, 1971). Because of the small amount involved in plants $(0.5-1.5$ per cent of the weight of nitrogenous compounds) and the low cost of resynthesis from monomers, DNA maintenance will be neglected.

The rate of mRNA turnover appears to be related to the rate of protein synthesis (Norris and Koch, 1972; Roth and Dampier, 1972) and is much higher than that of tRNA and rRNA in growing bacteria (Norris and Koch, 1972) and in growing Lemna minor (Table 1). The cost of RNA turnover in growing cells is small compared with the cost of amino acid polymerization (e.g. Stouthamer, 1974). Maintenance of RNA and enzymes for biosynthetic processes were estimated to consume the energy of about 1 ATP molecule per peptide bond (Penning de Vries, Brunsting and Van Laar, 1974). By analogy, it is assumed that the cost of maintaining proteases and their mRNA does not exceed 1 ATP molecule per peptide bond of the degraded proteins. Polymerization cost is 3 or 4 ATP molecules per peptide bond (Lucas-Lenard and Lipmann, 1971). Thus the minimum turnover cost per amino acid is about 5 or 6 ATP molecules per bond, which corresponds with $0 \cdot 22$ $0.26 \mathrm{~g}$ glucose per g protein.

Some amino acids are not recycled, but combusted and new amino acids are formed. This process causes ${ }^{14} \mathrm{CO}_{2}$ release from previously labelled proteins. Synthesis of $1.0 \mathrm{~g}$ of proteins requires $1.655 \mathrm{~g}$ glucose plus $\mathrm{NH}_{3}$, while its degradation yields $\mathrm{NH}_{3}$ plus as much energy as is obtained from $1.22 \mathrm{~g}$ glucose when it is completely oxidized. In this case protein and amino acid turnover require $0.43 \mathrm{~g}$ glucose per g protein. The latter value should be used when loss of ${ }^{14} \mathrm{CO}_{2}$ from labelled protein is determined, and one between these two values if loss of enzyme activity is measured. The magnitude of the fractions recycled and combusted is almost unknown (Hellebust and Bidwell, 1964a; Trewavas, 1972). From the different turnover rates of various amino acids observed by Trewavas in Lemna minor it may be inferred that an important fraction is recycled in that particular case; Lehninger (1970) mentions that in man over 75 percent of the amino acids are recycled.

From a detailed analysis of many experiments Shlyk (1970) reported an average rate of about $0 \cdot 10$ day $^{-1}$ for breakdown and de novo synthesis of chlorophyll in growing and mature leaves of higher plants. From the biochemical pathways leading to chlorophyll it can be calculated that synthesis of $1.0 \mathrm{~g}$ of chlorophyll requires $2.29 \mathrm{~g}$ glucose plus some $\mathrm{NH}_{3}$ and $\mathrm{Mg}$, while its breakdown yields about $1.5 \mathrm{~g}$ glucose per $\mathrm{g}$ chlorophyll. Leaves contain only 15-35 mg chlorophyll per g nitrogenous compounds, and it follows from these figures that the cost of chlorophyll turnover is much smaller than that of leaf proteins.

To calculate the approximate total cost of maintenance of the leaf nitrogenous compounds some assumptions can be made. Lexander, Carlsson, Schalen, Simonsson and Lundberg (1970) found that the non-protein nitrogen fraction in the leaves of 22 species was about 10 per cent of the total nitrogen fraction, with only two exceptions: Helianthus annuus ( 2.5 per cent) and Brassica napus (31 per cent). It is assumed therefore that, as an average, 10 per cent of leaf nitrogenous compounds are stable. Furthermore it is assumed that 44 per cent of total leaf organic nitrogen is in RuDPCase, and that this enzyme is degraded for $10 \mathrm{~h}$ per day at a rate of $0 \cdot 144 \mathrm{day}^{-1}$, that the resulting amino acids are stored in protein, that the enzyme is resynthesized for $6 \mathrm{~h}$ per day at a rate of 0.24 day $^{-1}$ and that RuDPCase is stable for $8 \mathrm{~h}$ per day. Three per cent of leaf organic nitrogen is assumed to be in chlorophyll, and the rest in proteins with a constant turnover rate of 0.15 day $^{-1}$. The cost of maintaining nitrogenous compounds can now be calculated to be between 28 and $53 \mathrm{mg}$ glucose per gram per day. 
Because the rate of protein synthesis is not constant (Peterson et al., 1973; Steer, 1973), also the cost of protein turnover shows a diurnal pattern. A relatively large fraction of these costs are required in the first hours after the onset of light. It is thus likely that induction of enzyme synthesis at a sudden onset of light causes an increase in energy requirement, and thus in respiration. Heichel (1970) reported a stimulation of maize leaf respiration for $2-3 \mathrm{~h}$ following illumination for $20 \mathrm{~min}$ in $\mathrm{CO}_{2}$-free air. These experiments were repeated by the present author with mature leaves of Lolium perenne, Phaseolus vulgaris, Zea mays and Helianthus annuus, grown in high light conditions. An illumination period of $60 \mathrm{~min}\left(300 \mathrm{~W} \mathrm{~m}^{-2}\right)$ was used, preceded by a period of darkness of $1-24 \mathrm{~h}$ in an atmosphere of 300 p.p.m. $\mathrm{CO}_{2}$. The 'post illumination burst', from which is subtracted the cost of translocation of the assimilates formed (Penning de Vries, 1974), was small after 1 and $3 \mathrm{~h}$ darkness, but about twice as large as that observed by Heichel after $6-24 \mathrm{~h}$ of darkness. Only in Lolium this stimulation remained small. The $\mathrm{CO}_{2}$ produced in this 'post illumination burst' is equal to the amount of $\mathrm{CO}_{2}$ formed when 1-4 per cent of the leaf proteins are broken down and others resynthesized. This is not an unusual large fraction, since Zucker (1972) reported that after induction 5-70 per cent of the proteins synthesized may be of a single species, the amount of which may well exceed 1 per cent of the total protein (Mandelstam, 1960; Tanner, Grünes, and Kandler, 1970; John, Thurston, and Syrett, 1970). It is suggested that the physiological phenomenon of 'post illumination respiration' and the biochemical phenomenon of enzyme induction are different aspects of the same process.

Breakdown and resynthesis of lipids. Bieleski (1972) observed that ${ }^{32} \mathrm{P}$ released from phospholipids in growing Spirodela was less than $0 \cdot 2$ day $^{-1}$. Kawaga, Lord, and Beevers (1973) measured the disappearance of ${ }^{14} \mathrm{C}$ from membranes in germinating castor bean endosperm, and observed rates of overall membrane turnover of 0.4-1.7 $\mathrm{day}^{-1}$, and of 4.8 day $^{-1}$ for a part of the 'light membrane fraction'. Lecithin molecules and even larger membrane fractions were possibly recycled. In non-growing animal cells membranes turned over at a rate of $0 \cdot 5-1 \cdot 2$ day $^{-1}$ (Pine, 1972). Estimating that 4 per cent of the dry weight consists of membranes (from estimates of total membrane surface, its thickness and density), and assuming arbitrarily that one-tenth of its proteins and lipids are completely degraded and resynthesized from glucose and that the rest is recycled, the cost of membrane maintenance is $1.7 \mathrm{mg}$ glucose per $\mathrm{g}$ dry matter per day.

Breakdown and resynthesis of other cell components. Bacterial cell wall components have been found to have a turnover rate of 0.3-1.0 per generation time (Mauck and Glaser, 1970), but cell walls of higher plants are stable. Holmsen and Koch (1964) found no labelling of polysaccharides after adding labelled glutamate to leaves. Auxin was shown to be rapidly degraded within the cell (turnover rate $34 \mathrm{day}^{-1}$, Dela Fuente and Leopold, 1970), but this involved an extremely small amount of material. Cell organelles are not turned over as units, except when they are very small (Pine, 1972).

Function of turnover. The function of turnover processes in plants may be briefly discussed here because of its important implications for plant productivity. Mandelstam's suggestion (1960) that protein breakdown and synthesis mainly provide a means of producing new enzymes when net cell growth has stopped is now widely accepted for bacteria and animals (Lehninger, 1970; Pine, 1972; cf. Siekevitz, 1972). It can account for the mode of adjustment of the biochemical machinery to environmental changes and possibly the anticipation thereof. Only the rapid and constant turnover of some proteins in growing bacteria is not explained by this hypothesis. Adaptation to a changed temperature can occur by formation of (iso-)enzymes in mature cells. Such a process has been observed for the enzyme NADP-isocitrate dehydrogenase in rainbow trout (Moon and Hochachka, 1971). Adaptation adds to success in competition and thus survival, but at the cost of protein turnover. 
Plant cells function in a variable physical environment, but their chemical environment is much more stable than that of bacteria. The time needed for adaptation of enzyme activity in leaf cells to a changed level of light intensity or temperature is considerably longer than the time needed by bacteria to respond to a modified medium. This allows the cost of protein turnover in plant cells to be correspondingly lower than in bacteria.

The degradation and resynthesis rates of $\mathrm{RuDPCase}, \mathrm{NO}_{3}^{-}$-reductase and other enzymes (Table 1) enable much more rapid adaptation than is required in modern agricultural systems, where much of the control of interspecific competition has been taken over by the farmer. For $\mathrm{NO}_{3}^{-}$-reductase and other rapidly vanishing enzymes in particular, the degradation rate seems to be more rapid than is required for adaptation processes under all circumstances (cf. Schimke, 1969). An artificial reduction in the rate of protein turnover could increase net crop growth rates, if the crop maintenance cost is lowered more than the reduction of assimilation caused by a decreased rate of adaptation to changing conditions. Complete removal of protein turnover would reduce maintenance cost by about $10 \mathrm{mg}$ glucose per $\mathrm{g}$ dry weight per day, or $10-40 \mathrm{~kg}$ carbohydrates per hectare per day. It is possible that a reduction of protein turnover in full-grown leaves can be obtained for a part or the whole growing season by use of chemicals, phytohormones or by plant breeding. Various substances have been shown to affect the rate of protein synthesis and degradation at different stages of growth. Chemicals and phytohormones inhibiting protein turnover would have to be applied in such a way that biosynthesis in growing parts was not reduced and reallocation of nitrogenous compounds in the reproductive phase was not hampered. Manipulating the maintenance processes may be useful in other fields of plant production, but the role of protein turnover in other characteristics, such as plant resistance against diseases, will need to be studied carefully.

Maintenance of ion concentrations. No major function for active transport of ions across cell membranes other than to maintain certain ion concentrations has been established. It has been suggested that part of the uptake of amino acids and glucose into animal cells is coupled to passive $\mathrm{Na}^{+}$influx (cf. Lehninger, 1970), and that ion uptake may be related to protein synthesis at membranes (Sutcliffe, 1973). By means of active transport systems, that move ions across plasmalemma and tonoplast at the expense of metabolic energy, cells maintain fairly constant ion concentrations in the cytoplasm under a range of conditions. These concentrations usually do not correspond with Donnan-equilibria (Hope, 1971). Compared with studies on active transport in nerve and muscle cells little research has been carried out on plant cells (Anderson, 1972). No values have been reported for ion fluxes across cell membranes in tissues of intact higher plants.

Active ion fluxes have been studied in algal cells and in dark-grown tissue sections of higher plants bathed in a nutrient solution. Data of active fluxes in steady-state conditions are collected in Table 2 . The ion composition of the liquid in the intercellular spaces of a root or leaf of an intact plant is different from that of a nutrient solution; nevertheless it is assumed that fluxes observed in nutrient solution give a fair impression of the order of magnitude of fluxes in vivo. In intact plants the ion concentration in xylem sap was found to be $0.1-0.7$ times that in a normal nutrient solution (cf. Milthorpe and Moorby, 1969). It is possible that ion concentrations are higher in intercellular spaces of leaves, from where water evaporates.

In autotrophic cells influx and efflux can be enhanced two- to fivefold by light (e.g. Hope, 1971), but only fluxes in darkness will be considered here. Possible higher expenses for active ion transport in the light are neglected because this study was conducted to provide an estimate of total maintenance cost in crop plants, and it is explained elsewhere (Penning de Vries, 1974) that all cost in addition to $\mathrm{CO}_{2}$-reduction is accounted for automatically if crop assimilation is computed from an observed leaf $\mathrm{CO}_{2}$-assimilation light response curve. 
TABLE 2. Some active fluxes across plasmalemma $(p)$ or tonoplast $(t)$ in darkness in steady state conditions

\begin{tabular}{|c|c|c|c|c|}
\hline Flux & Membrane & $\begin{array}{l}\text { Rate } \\
10^{-12} \mathrm{~mol} \mathrm{~cm}^{-2} \mathrm{~s}^{-1}\end{array}$ & Tissue and condition & Reference \\
\hline $\mathrm{K}^{+}$influx & $\mathrm{p}$ & $1 \cdot 4$ & $\begin{array}{l}\text { Avena sativa, coleoptile, in } \\
\text { nutrient solution }\end{array}$ & $\begin{array}{l}\text { Pierce and } \\
\text { Higinbotham, } 1972\end{array}$ \\
\hline $\mathrm{Na}^{+}$efflux & $\mathrm{p}$ & $>0.3$ & $\begin{array}{l}\text { Avena sativa, coleoptile, in } \\
\text { nutrient solution }\end{array}$ & $\begin{array}{l}\text { Pierce and } \\
\text { Higinbotham, } 1972\end{array}$ \\
\hline $\mathrm{Cl}^{-}$influx & $\mathrm{p}$ & 0.5 & $\begin{array}{l}\text { Avena sativa, coleoptile, in } \\
\text { nutrient solution }\end{array}$ & $\begin{array}{l}\text { Pierce and } \\
\quad \text { Higin botham, } 1972\end{array}$ \\
\hline $\mathrm{K}^{+}$influx & $\mathrm{t}$ & $1 \cdot 7$ & $\begin{array}{l}\text { Avena sativa, coleoptile, in } \\
\text { nutrient solution }\end{array}$ & $\begin{array}{l}\text { Pierce and } \\
\text { Higinbotham, } 1972\end{array}$ \\
\hline $\mathrm{Na}^{+}$influx & $t$ & $0 \cdot 3$ & $\begin{array}{l}\text { Avena sativa, coleoptile, in } \\
\text { nutrient solution }\end{array}$ & $\begin{array}{l}\text { Pierce and } \\
\text { Higinbotham, } 1972\end{array}$ \\
\hline $\mathrm{Cl}^{-}$influx & $t$ & $0 \cdot 1$ & $\begin{array}{l}\text { Avena sativa, coleoptile, in } \\
\text { nutrient solution }\end{array}$ & $\begin{array}{l}\text { Pierce and } \\
\quad \text { Higinbotham, } 1972\end{array}$ \\
\hline $\mathrm{K}^{+}$influx & $\mathrm{p}$ & 0.7 & $\begin{array}{l}\text { Pisum sativum, epicotyl, in } \\
\text { nutrient solution }\end{array}$ & $\begin{array}{l}\text { Macklon and } \\
\text { Higinbotham, } 1970\end{array}$ \\
\hline $\mathrm{K}^{+}$influx & $\mathfrak{t}$ & $1 \cdot 0$ & $\begin{array}{l}\text { Pisum sativum, epicotyl, in } \\
\text { nutrient solution }\end{array}$ & $\begin{array}{l}\text { Macklon and } \\
\text { Higinbotham, } 1970\end{array}$ \\
\hline All ions, efflux & $\mathrm{p}$ & $1 \cdot 3-2 \cdot 8$ & Nitella sp. & Vredenberg, 1972 \\
\hline $\mathrm{K}^{+}$influx & $\mathrm{p}$ & $15 \cdot 0-30 \cdot 0$ & Acetabularia sp. & Saddler, 1970 \\
\hline $\mathrm{Na}^{+}$efflux & $\mathrm{p}$ & $3 \cdot 0-10 \cdot 0$ & Acetabularia sp. & Saddler, 1970 \\
\hline
\end{tabular}

In animal cells and mitochondria ion extrusion or accumulation and ATP consumption are clearly related (Stein, 1967; Lehninger, 1970). Extrusion of $\mathrm{Na}^{+}$from the cell requires about 1 ATP molecule per translocated ion. This transport occurs by two mechanisms, in one of which uptake of $\mathrm{K}^{+}$is coupled to export of $\mathrm{Na}^{+}$in a $1: 1$ relation. In the other mechanism uptake of $\mathrm{K}^{+}$, other ions, amino acids and glucose, is loosely coupled to $\mathrm{Na}^{+}$; $\mathrm{Ca}^{2+}$ and inorganic $\mathrm{P}$ are taken up at a cost equivalent to 0.6 and $1.0 \mathrm{ATP}$ molecules, respectively (Lehninger, 1970). Higher plants seem to use different transport mechanisms: active $\mathrm{Na}^{+}$efflux has been observed, but also active $\mathrm{K}^{+}$and $\mathrm{Cl}^{-}$influx independent of $\mathrm{Na}^{+}$ extrusion. Formation of these transport systems is often inducible (Anderson, 1972). Information about the energy cost of moving ions across plasmalemma or tonoplast is mainly qualitative (Anderson, 1972), but it is unlikely that these processes are much less efficient in plants than in animals. Fisher and Hodges (1969) and Kirk and Hanson (1973) reported values of $0.6-1.0 \mathrm{~K}^{+}$ion taken up per ATP molecule in maize mitochondria, and such values were also found for erythrocytes (Lehninger, 1970). There is still discussion whether ATP is used as an intermediate to provide energy for transport (Anderson, 1972), but the net cost of such mechanisms can always be expressed in ATP units, since finally energy consumption is always competitive with ATP production.

To obtain an order of magnitude of the energy consumption for active ion transport in plants, it is assumed on the basis of the information of Table 2, that active fluxes amount to $1-2 \times 10^{-12} \mathrm{~mol}$ per $\mathrm{cm}^{2}$ plasmalemma per s. Furthermore, it is assumed that a considerable fraction of this flux represents coupled active transport, and that per active ion movement the energy of 1 ATP molecule is required. Cells with dimensions of $40 \times 40 \times 40 \mu \mathrm{m}$ have about $1.2 \times 10^{4} \mathrm{~cm}^{2}$ plasmalemma per g dry weight. From such numbers it follows that maintenance of these fluxes consumes about $4 \mathrm{mg}$ glucose per $\mathrm{g}$ dry weight per day. In young and small cells this value may be larger, while in large parenchyma cells it is likely to be lower. Active fluxes across the tonoplast may be roughly similar to those across the plasmalemma (Table 2). Pitman (1969), on the basis of simulation, concluded that there are considerable ion fluxes across the tonoplast in barley root cells, and Lüttge, Cram, and Laties (1971) concluded that salt-stimulated respiration above 
a salt concentration of $0.5 \mathrm{~mm}$ is related to transport across the tonoplast. Without much evidence it is assumed that other membranes do not require much energy to maintain ion gradients, and that the cost of re-absorption of glucose and amino acids leaked from the cell are negligible. The total energy requirement for maintenance of ion gradients across cell membranes is thus estimated to be $6-10 \mathrm{mg}$ glucose per $\mathrm{g}$ dry weight per day. Lack of more data does not permit assessment of the generality of this estimate in various plants and plant parts.

When the total maintenance requirement for plant tissue is about $40 \mathrm{mg}$ glucose per $\mathrm{g}$ dry weight per day, the cost of maintaining ion gradients corresponds to about 20 per cent of the total. This value is similar to that estimated by Keynes and Maisel (1954) for the relative cost of this process in resting frog muscle cells. The respiratory energy of erythrocytes and active kidney cells, however, is required mainly for maintenance of the ion gradient (Netter, 1969, p. 763) and ion uptake (Lehninger, 1970, p. 616), respectively.

The high active fluxes in Acetabularia (Table 2) can be maintained only because of the small surface-volume ratio of the large cells. The surface-volume ratio of bacteria is very much larger, and it can be inferred that either their membrane permeability is lower or the gradient maintained is much smaller. Stouthamer and Bettenhausen (1973) observed that maintenance respiration in Azotobacter aerogenes is enhanced by increasing $\mathrm{NH}_{4} \mathrm{Cl}$ concentration in the medium, but this is not so in Azorobacter vinelandii because of highly impermeable membranes (Knowles and Smith, 1971). This difference demonstrates the variability that exists among species in this respect.

Other maintenance processes and wasteful respiration. There is no evidence that a significant amount of respiratory energy is used in plants to provide heat (except in a few, particular cases), or for displacement other than of ions. Active leaf movements require very small amounts of energy. There is some indication (Pickard, 1972) that protoplasmic streaming is not a separate energy-requiring process, but results from other processes. The energy spent to transport substances in the phloem probably requires a small fraction of the total amount transported in agricultural plants (Penning de Vries, 1974). Such expenses are therefore often neglected if whole plants are considered, but they may cause a significant fraction of the metabolic activity in phloem cells.

Beevers (1970) suggested that a considerable part of the glucose consumed in mature leaves may be degraded by the pentose phosphate pathway, as an alternative to glycolysis and Krebs cycle. The $\mathrm{NADPH}_{2}$ generated by this pathway is mainly oxidized by cytoplasmic oxidases, and does not yield ATP. Baddeley and Hanson (1967) observed that a high concentration of fatty acids decreased the $\mathrm{P}: \mathrm{O}$ ratio of plant cell mitochondria. No conclusive evidence has as yet been found that such processes are important in vivo, but the existence of 'uncoupled' or 'idling' respiration in plants has been suggested to explain unexpected high respiration rates (Beevers, 1970) and low yields (Tanaka, 1972). It was suggested (p. 82) that a part of protein turnover may represent a process of little use, e.g. the rapid degradation and resynthesis of $\mathrm{NO}_{3}^{-}$-reductase. Wasteful processes related to biosynthesis are absent in rapidly growing maize and sunflower plants (Penning de Vries, 1972, 1974). To what extent climateric respiration in fruits is caused by wasteful processes is unknown.

\section{MEASURED MAINTENANCE RESPIRATION RATES}

The maintenance respiration rate of organs that are not growing or transporting substances can be determined directly from $\mathrm{CO}_{2}$ evolution rates, assuming the absence of idling respiration. Care should be taken in preparing the samples since cutting or slicing can affect the internal structure and the metabolic rate considerably (Eberhardt, 1960; MacDonald, 1968). Some measurements obtained in this way (method a) are presented in Table 3; their values are always very low. 
Measuring the rate of maintenance respiration is more complicated when maintenance processes are accompanied by biosynthesis of structural dry matter or by active translocation of sugars and amino acids. If the latter processes are stopped, the rate of maintenance processes may alter. Moreover, the rate of protein turnover in mature leaves is probably maximal in the morning, after the onset of light (p. 81), and is sensitive to environmental changes. Fortunately protein metabolism in darkness does not seem to be altered much until nearly all the soluble carbohydrates are consumed (James, 1953; Hellebust and Bidwell, 1964b). These may last 6-24 h, or even a few days in leaves of some species (James, 1953). The respiratory quotient in this period remains at about unity.

One method of determining the rate of sugar consumption for maintenance processes is to extrapolate the relation between growth rate (increase in structural dry weight) or rate of export of assimilates and respiration rate to zero (cf. Penning de Vries, 1974), assuming that the rate of maintenance processes is independent of transport and biosynthesis processes. To avoid changes in the system to be maintained, the measurements must not be taken over long time intervals. There is no easy way to obtain a range of growth rates within one day without changing the conditions for maintenance processes also. (Although the $\mathrm{CO}_{2}$-assimilation rate of leaves can be changed instantaneously, the growth rate responds slowly due to the buffering capacity of the pool of reserve carbohydrates.) Some data obtained by this method (b) are given in Table 3 . The considerable variation in the data suggests that the method is not accurate. This extrapolation method has been used also to determine the maintenance requirement of animals (Kleiber, 1961) and of growing bacteria. Since growth and maintenance processes are not independent in bacteria the 'maintenance rate' obtained in this way is only valid for growing bacteria (cf. Pirt, 1965). In higher plants this complication is absent, since at all growth rates most plant cells are mature and do not increase in structural dry weight (total dry weight minus reserve substances); only seedlings may be an exception.

Another method of determining maintenance respiration (c) involves measurement of the rate of $\mathrm{CO}_{2}$ production of attached organs under conditions where growth and translocation are absent, but maintenance is unaffected. Mature leaves after $6-24 \mathrm{~h}$ in darkness are used in most cases. Values obtained by this method are somewhat larger than those obtained by (b), but a few very low values have been found as well (Table 3 ). This method is inaccurate because it is difficult to establish whether all processes except maintenance have stopped.

The fourth method (d) of determining maintenance respiration involves measurement of the rate of respiration or the rate of dry weight decrease of full-grown, detached organs. If these are not exhausted of carbohydrates the respiration rate does not change much during the first few days (James, 1953). In well-designed experiments, wound respiration contributes little to the total $\mathrm{CO}_{2}$-evolution. Thus rates observed with leaves of wellilluminated plants for the first day after detachment probably approximate to normal rates. Examples of such rates are presented in Table 3, and are similar to those obtained by other methods; the high values for primary bean leaves (80 and 55) probably reflect some remaining biosynthetic activity. The very high rates reported by James (up to 150) must be erroneous since not enough carbohydrates were present to sustain such high rates for the 7 days, as was reported.

Table 3 shows a range of maintenance respiration rates of $8-60 \mathrm{mg}$ glucose per $\mathrm{g}$ dry weight per day at $25^{\circ} \mathrm{C}$. The information is still too limited to decide whether different species have different rates of maintenance respiration under similar conditions, but that of $H$. annuus seems always higher than that of $Z$. mays. A comparison of the values for one species at one temperature (Table 3) shows that leaves with high assimilation rates in the days preceding the measurement have higher maintenance respiration rates than those with low assimilation rates. This suggests that there is a relation between whole 
TABLE 3. Maintenance respiration rates obtained with various methods

\begin{tabular}{|c|c|c|c|c|}
\hline Species and organ & Conditions & $\begin{array}{l}\text { Maintenance } \\
\text { respiration rate }\end{array}$ & Method & Reference \\
\hline $\begin{array}{l}\text { Avena sativa and Hordeum vulgare, } \\
\text { seeds }\end{array}$ & water content $9-11 \%$ & $0.0002-0.0010$ & a & 1 \\
\hline Pisum sativum, seeds & air dried & 0.0039 & a & 1 \\
\hline Various conifers, stem wood & core, $\mathrm{T}=15$ & $0 \cdot 02-0 \cdot 13$ & a & 2 \\
\hline Various conifers, stem wood & bark, $\mathrm{T}=15$ & $1 \cdot 3$ & $\mathrm{a}$ & 2 \\
\hline Aspergillus niger, mycelium & $\begin{array}{l}\mathrm{T}=30,\left[\mathrm{O}_{2}\right]=80 \% \\
\text { non growing }\end{array}$ & $337 \cdot 0$ & a & 3 \\
\hline Trifolium repens, plants & $\mathrm{T}=20, \mathrm{~L}$ & $15 \cdot 0$ & $\mathrm{~b}$ & 4 \\
\hline Gossypium sp., bolls & field conditions & $6 \pm 10$ & $\mathrm{~b}$ & 5 \\
\hline Helianthus annuts, plants & $P=24, T=18, M$ & $28 \cdot \overline{0}$ & b & 6 \\
\hline Helianthus annuus, plants & $\mathrm{P}=24, \mathrm{~T}=25, \mathrm{M}$ & $47 \cdot 0$ & $\mathrm{~b}$ & 6 \\
\hline Helianthus annuus, plants & $\mathrm{P}=15, \mathrm{~T}=25, \mathrm{M}$ & $41 \cdot 0$ & $\mathrm{~b}$ & 6 \\
\hline Zea mays, plants & $\mathrm{P}=23, \mathrm{~T}=18, \mathrm{M}$ & $7 \cdot 0$ & $\mathrm{~b}$ & 6 \\
\hline Zea mays, plants & $\mathrm{P}=23, \mathrm{~T}=25, \mathrm{M}$ & $15 \cdot 0$ & $\mathrm{~b}$ & 6 \\
\hline Zea mays, plants & $\mathrm{P}=23, \mathrm{~T}=33, \mathrm{M}$ & $44 \cdot 0$ & $\mathrm{~b}$ & 6 \\
\hline Helianthus annuus, leaves & $\mathrm{T}=25, \mathrm{H}$ & $60 \cdot 0$ & $\mathrm{c}$ & 7 \\
\hline Zea mays, leaves & $\mathrm{T}=25, \mathrm{H}$ & $40 \cdot 0-60 \cdot 0$ & $\mathrm{c}$ & 7 \\
\hline Zea mays, leaves & $\mathrm{T}=25, \mathrm{H}$ & $57 \cdot 0$ & $\mathrm{c}$ & 8 \\
\hline Zea mays, leaves & $\mathrm{T}=25, \mathrm{~L}$ & $39 \cdot 0$ & c & 8 \\
\hline Zea mays, leaves & $\mathrm{T}=25, \mathrm{~L}$ & $8 \cdot 0-10 \cdot 0$ & $\mathrm{c}$ & 9 \\
\hline Lolium perenne, leaves & $\mathrm{T}=25, \mathrm{H}$ & $40 \cdot 0$ & $\mathrm{c}$ & 7 \\
\hline Phaseolus vulgaris, leaves & $\mathrm{T}=25, \mathrm{H}$ & $80 \cdot 0$ & $\mathrm{c}$ & 7 \\
\hline Phaseolus vulgaris, leaves & $\mathrm{T}=25, \mathrm{~L}$ & $12 \cdot 0$ & $\mathrm{c}$ & 10 \\
\hline Phaseolus multiflorus, leaves, & & & & \\
\hline 14 days old & $\mathrm{T}=18-25, \mathrm{~L}$ & $55 \cdot 0$ & $\mathrm{c}$ & 11 \\
\hline $\begin{array}{l}\text { Phaseolus multifiorus, leaves, } \\
28 \text { days old }\end{array}$ & $\mathrm{T}=18-25, \mathrm{~L}$ & $25 \cdot 0$ & $\mathrm{c}$ & 11 \\
\hline Phaseolus multiflorus, leaves, & & & & \\
\hline $\begin{array}{l}48 \text { days old } \\
\text { Phaseolus multiflorus leaves. }\end{array}$ & $\mathrm{T}=18-25, \mathrm{~L}$ & $18 \cdot 0$ & c & 11 \\
\hline $\begin{array}{l}\text { Phaseolus multiflorus, leaves, } \\
24 \text { days old }\end{array}$ & $\mathrm{T}=20, \mathrm{~L}$, daylength $=6 \mathrm{~h}$ & $18 \cdot 0$ & $\mathrm{c}$ & 11 \\
\hline $\begin{array}{l}\text { Phaseolus multiflorus, leaves, } \\
24 \text { days old }\end{array}$ & $\mathrm{T}=20, \mathrm{~L}$, daylength $=12 \mathrm{~h}$ & $18 \cdot 0$ & $\mathrm{c}$ & 11 \\
\hline $\begin{array}{l}\text { Phaseolus multiflorus, leaves, } \\
24 \text { days old }\end{array}$ & $\mathrm{T}=20, \mathrm{~L}$, daylength $=18 \mathrm{~h}$ & $30 \cdot 0$ & c & 11 \\
\hline Hordeum sp. and Triticum sp., & & & & \\
\hline leaves & $\mathrm{T}=20$ & $50-150$ & $\mathrm{~d}$ & 12 \\
\hline Prunus laurocerasus & $\mathrm{T}=20$ & $10-20$ & $\mathrm{~d}$ & 12 \\
\hline Zea mays, leaves & $\mathrm{T}=20, \mathrm{M}$ & $27 \pm 10$ & $\mathrm{~d}$ & 7 \\
\hline Zea mays, leaves & $\mathrm{T}=25, \mathrm{M}$ & $26 \pm 10$ & $\bar{d}$ & 7 \\
\hline Zea mays, leaves & $\mathrm{T}=30, \mathrm{M}$ & $46 \pm 10$ & $\mathrm{~d}$ & 7 \\
\hline Phaseolus vulgaris, leaves & $\mathrm{T}=25, \mathrm{M}$ & $27 \pm 10$ & d & 7 \\
\hline
\end{tabular}

$\mathrm{P}$ stands for the tissue protein content (per cent) and $\mathrm{T}$ for temperature $\left({ }^{\circ} \mathrm{C}\right)$; the assimilation rate in the days prior to measurement is indicated by $\mathbf{H}$ (high, in full sunlight), $\mathbf{M}$ (moderate) or $\mathbf{L}$ (low, at $100 \mathrm{~W} \mathrm{~m}^{-2}$ or less). The respiration rate is expressed in $\mathrm{mg}$ glucose per $\mathrm{g}$ dry matter per day; values originally expressed in other units were converted, assuming a respiratory quotient of 1 .

References: 1 Huber and Ziegler, 1960; 2 derived from Yoda et al., 1965; 3 Tamiya and Yamagutchi, 1933; 4 McCree, 1970; 5 Thornley and Hesketh, 1972; 6 Penning de Vries, 1974; 7 Penning de Vries and Van Laar, unpublished; 8 derived from Heichel, 1970; 9 Alberda, unpublished; 10 Louwerse, unpublished; 11 Prinz zur Lippe, 1956; 12 James, 1953.

plant metabolic activity and maintenance costs. A similar result was obtained by Tamiya and Yamagutchi (1933), who described a component of maintenance respiration related to the growth rate in Aspergillus niger of 12 per cent of the total substrate consumption at $30^{\circ} \mathrm{C}$ and an oxygen concentration of 80 per cent. The possibility might be investigated 
that active ion fluxes across cell membranes require an amount of energy per $g$ dry weight independent of the assimilation rate while protein turnover consumes an amount of energy equivalent to 2-7 per cent of the daily gross assimilation.

The rate of maintenance respiration predicted from basic data equals $15-25 \mathrm{mg}$ glucose per g dry matter per day, and is lower than measured values for plants grown under high light intensities, but is about the same in other cases. It is suggested that this should be attributed to the fact that protein turnover rates used for prediction were not obtained from plants grown at high light intensities, but from less active ones. In a simulation of growth of a maize crop De Wit, Brouwer, and Penning de Vries (1970) assumed that maintenance processes consume $15 \mathrm{mg}$ glucose per g dry matter with 4 per cent nitrogen per day. The simulated growth rate agreed well with observed rates, while doubling the maintenance cost reduced the simulated growth rate too much. However, not only the rate of maintenance respiration was underestimated in this model, but probably also the crop assimilation rate. Ryle, Brockington, Powell, and Cross (1973) used a value of 30 $\mathrm{mg}$ glucose per $\mathrm{g}$ dry matter per day to simulate growth of uniculm barley and obtained an encouraging agreement between experimental and simulated results.

It is obvious that measuring the rate of maintenance respiration is a difficult task, and it is not surprising that in spite of the enormous amount of work done on plant respiration only a few values can be interpreted as maintenance respiration with reasonable certainty. For a better understanding of the various processes many more observations are needed, especially with reference to metabolic activity. Because the rates of individual maintenance processes are variable and because the respiration rate due to these processes is easily exceeded by that of other processes, it seems that the methods described previously are not suitable for accurate determinations of maintenance respiration in plants. A better approach of maintenance respiration is the study of the rates of the underlying biochemical processes, and especially of their control.

EFFECT OF ENVIRONMENTAL FACTORS ON MAINTENANCE PROCESSES The effects of growth retardants will not be covered in this paper, although it is well known that these may influence protein synthesis and degradation and decrease the efficiency of oxidative phosphorylation. The effects of plant disease will not be considered either.

Numerous measurements have been made of the effects of environmental factors on plant and leaf respiration rates, many of which are presented in the Encyclopedia of Plant Physiology, volume 12.2. However, frequently the contribution of $\mathrm{CO}_{2}$ from biosynthetic processes to the total $\mathrm{CO}_{2}$ production is not known, or the effect of the changed factor on the rate of these biosynthetic processes. As a result, little is known about the effects of environmental factors on the rate of maintenance processes. Measurements in which the change of an environmental condition persists should be distinguished from short term changes, because adaptation processes may modify responses.

Temperature. Lyons and Raison (1970) demonstrated that temperature did not alter the P:O ratio in isolated mitochondria of several species between $1.5^{\circ} \mathrm{C}$ and $25^{\circ} \mathrm{C}$. Probably because the procedure followed in preparing mitochondria was not ideal (cf. Romani and Ozelkok, 1973) absolute values of the P:O ratios were fairly low (1.5). Chilling of cold resistant cucumber varieties did not affect the $\mathrm{P}: \mathrm{O}$ ratio, but it was decreased from 1.5 to 0.5 in non-resistant varieties (Kushnirenko, Kurkova, Rogacheva, and Zholkevich, 1969). The $\mathrm{P}: \mathrm{O}$ ratio may usually be about 3 in the range of temperatures normal to a plant, but reduced at higher or lower temperatures.

The rate of thermal protein denaturation increases exponentially with temperature, but it is fairly small at temperatures normal to the species considered (Morowitz, 1968). The only description found of experiments about effects of temperature on the rate of active protein turnover concerns $E$. coli, where the rate of protein degradation increased exponentially from about 0.2 day $^{-1}$ at $25^{\circ} \mathrm{C}$ to about 2.0 day $^{-1}$ at $45^{\circ} \mathrm{C}$; up to $42{ }^{\circ} \mathrm{C}$ the 
rate of degradation was probably equal to that of resynthesis (Pine, 1973). In thermophilic bacteria the rate of protein turnover at $70^{\circ} \mathrm{C}$ is not higher than that of mesophilic bacteria at $35^{\circ} \mathrm{C}$ (Pine, 1972).

The increase in the diffusion coefficient of ions with temperature is small (about 1.3 per $10^{\circ} \mathrm{C}$ ), but the response of membrane permeability to temperature is considerable in animal cells (Stein, 1967) and in algae (e.g. Thorhaug, 1971). Hope (1971) reports that active fluxes are enhanced three- to fourfold per $10^{\circ} \mathrm{C}$ temperature increase in nerve cells, and Waisel (1972) presents some indirect evidence for a smaller response in plants. A large increase in the cost of maintenance of ion concentrations with increased temperature is in agreement with observations that high temperatures amplify the damaging effect of saline media (Strogonov, 1964).

The basic information thus suggests that temperature increase raises the cost of maintenance by a considerable stimulation of protein turnover and of active ion fluxes. Although at the present stage of knowledge, a prediction of how the maintenance respiration rate in higher plants responds quantitatively to a change in temperature is of little value, the above conclusion seems confirmed by direct respiration measurements, in which often a stimulation of $\mathrm{CO}_{2}$ production has been reported of about threefold per $10{ }^{\circ} \mathrm{C}$ temperature increase at low temperature to twofold at higher temperatures from below $0{ }^{\circ} \mathrm{C}$ in some species up to $45^{\circ} \mathrm{C}$ in others (Yamamoto, 1933; Forward, 1960, Table 3). Unfortunately, many of these measurements were made in short-term experiments, and thus may not always be representative of long-term changes (cf. Forward, 1960).

Water stress and salinity. Water stress and salinity are considered together because these processes both cause an increased ion concentration in cells. In spite of the agricultural importance of these factors, there is as yet little insight into their effects at the biochemical and cellular level. Effects of salinity on plant growth were reviewed recently by Waisel (1972).

In media with high salt concentration the $\mathrm{P}: \mathrm{O}$ ratio of isolated mitochondria remains unaffected (e.g. Greenway and West, 1973). Morozovskii and Kabanov (1970) found that the P:O ratio of the salinity-sensitive species did not decrease up to a soil $\mathrm{NaCl}$ concentration of 0.4 per cent, and that of a salt-resistant species up to 2 per cent. In these experiments absolute values of the P:O ratio were fairly low. A direct effect of water stress on the efficiency of oxidative phosphorylation has not been found. It appears therefore that water stress and salinity at a level normal to the species considered do not uncouple oxidative phosphorylation.

The activity of many enzymes decreases when water stress persists, while that of other enzymes remains unaffected (e.g. Bardzik, Marsh, and Havis, 1972). Similar responses were observed in plants at media salinized with various salts. The reactions of glycophytes at low salt levels differed from that in halophytes (Waisel, 1972).

No report has been found about the effect of water stress or salinity on the active fluxes across cell membranes. Osmotic shrinkage of the cell size did not affect the respiration rate of Azotobacter vinelandii (Knowles and Smith, 1971). An increase of the plant salt concentration generally stimulates processes for maintenance of ion concentrations (Waisel, 1972), but how soil salinity affects ion gradients across cell membranes is uncertain. It is most likely that the type of salt causing salinity also affects the degree of stimulation of these maintenance processes.

An increasing water shortage reduced the rate of respiration of mature leaves to less than 50 per cent of its initial value (Huber and Ziegler, 1960; Boyer, 1970; Gordon and Bichurina, 1970); that of oat seedlings, however, doubled (Huber and Ziegler, 1970). Rehydration increases respiration rates temporarily two- to sixfold (Huber and Ziegler, 1960), which probably results from enzyme induction and other biosynthetic processes. The energy requirement for maintenance in Saccharomyces cerevisiae in a $1.0 \mathrm{M}-\mathrm{NaCl}$ medium is four times larger than in a $\mathrm{NaCl}$ free medium (Watson, 1970). 
On the basis of these observations at various levels, it is expected that continuous water stress reduces the rate of maintenance respiration mainly via a decrease of the total metabolic activity of the plant (although the turnover rate of some enzymes may be increased), and that a short period of water stress modifies it only slightly. Salinity, however, can increase the cost of maintaining intracellular ion concentrations markedly. (Thus roots with a high ion selection capacity and salt excreting leaf cells may protect the majority of cells against the development of unnecessary gradients, and maintenance cost. Consequently, both are a facet of plant salt resistance (cf. Waisel, 1972).)

Starvation from nutrients or carbohydrates. Zaitseva, Titova, and Sarsenbaev (1970) reported that short term P-deficiency did not decrease 'mitochondrial functioning', although it reinforced a growth rate reduction in water-stressed and in flooded plants (Samuilov, Gordon, Petrov, and Bichurina, 1970). When grow th of E. coli and of Torulopsis utilis is limited by iron the P:O ratio falls from 3 to about 1 (Rainnie and Bragg, 1973). Trewavas (1972) found that absence of $\mathrm{NO}_{3}^{-}, \mathrm{PO}_{4}^{3-}, \mathrm{SO}^{2}, \mathrm{Mg}_{4}^{2+}$, or $\mathrm{Ca}^{2+}$ increased the rate of protein turnover in Lemna minor two- to threefold. In $E$. coli the rate of proteolysis is about doubled in amino acid starved cells (Pine, 1973). Syrett (1960) reported that deficiency of $\mathrm{K}^{+}, \mathrm{Mg}^{2+}$ and $\mathrm{Ca}^{2+}$ slightly increased the respiration rate of plants, while severe deficiency of these and of $\mathrm{N}$ and of $\mathrm{P}$ decreased metabolic activity and respiration. It seems thus that starvation of nutrients increases the cost of maintenance of plant cells.

Starvation of carbohydrates induced by prolonged darkness generally forces the cell to degrade protein. The term 'maintenance' is confusing in this situation since the plant does not maintain its structure. It has often been observed that plant productivity is depressed at high night temperatures (e.g. Went, 1957). At relatively high temperatures the maintenance cost is large and the rate of biosynthetic processes is stimulated, so that the pool of reserve carbohydrates can be depleted before the end of the night (Challa, personal communication). The resulting damaging effect of a high night temperature is avoided when the night period is sufficiently short to prevent exhaustion, or when sufficient reserves are formed in daytime. Translocation of sugar from leaves of tomato plants stops at high night temperatures (Went, 1957), so that carbohydrate starvation in heterotrophic parts results, in spite of the presence of reserves in the plants.

Oxygen, carbon dioxide, ozone and U.V. radiation. The effects of a wide range of $\mathrm{O}_{2}$ and $\mathrm{CO}_{2}$ concentrations on dark respiratory processes are small, in contrast to their effects on photorespiration. The rate of $\mathrm{O}_{2}$ diffusion into thick tissues is usually sufficient to avoid anaerobic conditions (MacDonald, 1968). At a high $\mathrm{O}_{2}$ concentration (80 per cent) the growth rate of yeast is reduced (e.g. Tamiya and Yamagutchi, 1933), possibly due to stimulation of protein turnover by its oxidation.

Ozone and U.V. radiation destroy cell structures, and thus stimulate repair processes (e.g. Das, Malinoff, and Bhattacharjee, 1972), but under normal conditions their effects are negligible for respiration studies. Even in polluted areas the ozone concentration remains generally below a concentration that stimulates maintenance respiration noticeably (cf. Pell and Brennan, 1973).

\section{ACKNOWLEDGEMENTS}

$\mathrm{Mr}$ B. Boerboom made a compilation of relevant literature at an early stage of this report. Discussions with Dr A. H. Stouthamer and Dr Ir. C. T. de Wit were most valuable and their help is greatly appreciated. Miss A. H. van Rossem kindly corrected the English text.

\section{LITERATURE CITED}

ANDERson, W. P., 1972. Ion transport in the cells of higher plant tissues. A. Rev. Pl. Physiol. 23, 51-72 BADDELEY, M. S. and HANSON, J. B., 1967. Uncoupling of energy-linked functions of corn mitochondria by linoleic acid and monomethyldecenylsuccinic acid. Pl. Physiol. 42, 1702-10. 
BARDzik, J. M., Marsh, H. V., and Havis, J. R., 1971. Effects of water stress on the activities of three enzymes in maize seedlings. Ibid. 47, 828-31.

BeEvers, H., 1961. Respiratory Metabolism in Plants. Harper and Row, New York.

- 1970. Respiration in plants and its regulation. In Prediction and Measurement of Photosynthetic Productivity, pp. 209-14. Pudoc, Wageningen.

Beevers, L. and Hageman, R. H., 1969. Nitrate reduction in higher plants. A. Rev. Pl. Physiol. 20, 495-522.

Breleski, R. L., 1972. Turn over of phospholipids in normal and phosphorus deficient Spirodela. Pl. Physiol. 49, 470-5.

BOYER, J. S., 1970. Leaf enlargement and metabolic rates in corn, soybean and sunflower at various leaf water potentials. Ibid. $46,233-5$

Das, J., Malinoff, J., and BhatTaCharJee, S. B., 1972. Dark and light repair in ultraviolet-irradiated Acholeplasma laidlawii. Biochim. biophys. Acta 159, 189-97.

Dela Fuente, R. K. and Leopold, A. C., 1970. Turn over in the transportable pool of auxin. Pl. Physiol. $45,642-3$.

Dyer, T. A. and OsBorne, D. J., 1971. Leaf nucleic acids. J. exp. Bot. 22, 552-60.

EBerHARDT, F., 1960. Der Einfluss von mechanischer Beanspruchung, Verletzung, und Infektion auf die Atmung. Handbuch der Pfanzenphysiologie, Vol. 12.2, pp. 388-412. Ed. W. Ruhland. SpringerVerlag, Heidelberg.

Fisher, J. and Hodges, T. K., 1969. Monovalent ion stimulated adenosine triphosphate from oats roots. Pl. Physiol. 44, 385-95.

ForWARD, D. F., 1960. Einflüsse auszerer Faktoren auf die Atmung. 3A. Effect of temperature on respiration. Handbuch der Pflanzenphysiologie, Vol. 12.2, pp. 234-55. Ed. W. Ruhland. Springer-Verlag, Heidelberg.

Glasziou, K. T., 1969. Control of enzyme formation and inactivation in plants. A. Rev. Pl. Physiol. 20, 63-88.

Gordon, L. K. and BichurinA, A. A., 1970. Effect of increasing water deficit on respiratory metabolism in plants. Dokl. Akad. Nauk. SSSR Bot. Sci. 192, 36-8.

GreENWAY, H. and WeST, K. R., 1973. Respiration and mitochondrial activity in Zea mays roots as affected by osmotic stress. Ann. Bot. 37, 21-35.

Herchel, G. H., 1970. Prior illumination and the respiration of maize leaves in the dark. Pl. Physiol. $46,359-62$.

Hellebust, J. A. and Bidwell, R. G. S., 1964a. Protein turn over in attached wheat and tobacco leaves. Can. J. Bot. 42, 1-12.

- 1964b. Protein metabolism and respiration in attached and detached primary wheat leaves. Ibid. $42,357-66$.

HolmSEN, T. W. and $\mathrm{KoCH}$, A. L., 1964. An estimate of protein turn over in growing tobacco plants. Phytochemistry 3, 163-72.

Hope, A. B., 1971. Ion Transport and Membranes. Butterworth and Co., London.

Huber, B. and Ziegler, H., 1960. Einflüsse auszerer Faktoren auf die Atmung. 2. Wasser und Mineralsalze. Handbuch der Pflanzenphysiologie, Vol. 12.2, pp. 150-67. Ed. W. Ruhland, Springer-Verlag, Heidelberg.

JAMES, W. O., 1953. Plant Respiration. Clarendon Press, Oxford.

John, P. C. L., Thurston, C. F., and Syretr, P. J., 1970. Disappearance of isocitrate lyase enzyme from cells of Chlorella pyrenoidosa. Biochem. J. 119, 913-9.

KaWAGA, T., LoRD, J. M., and BEEvers, H., 1973. The origin and turn over of organelle membranes in castor bean endosperm. Pl. Physiol. 51, 61-5.

KEYNES, R. D. and MAISEL, G. W., 1954. The energy requirement for sodium extrusion from a frog muscle. Proc. R. Soc. B.142, 383-92.

KIRK, B. I. and Hanson, J. B., 1973. The stoichiometry of respiration-driven potassium transport in corn mitochondria. Pl. Physiol. 51, 357-62.

KLeIBer, M., 1961. The Fire of Life. Wiley and Sons, New York.

KNOWLeS, CH. J. and SMITH, L., 1971. Effect of osmotic pressure of the medium on the volume of intact cells of Azotobacter vinelandii and on the rate of respiration. Biochim. biophys. Acta 234, 144-52.

Kushnirenko, S. V., Kurkova, E. B., Rogacheva, A. Yu., and Zholkevich, V. N., 1969. Influence of low positive temperatures on oxidative phosphorylation and ultrastructure of the mitochondria in Cucumis sativus L. Soviet Pl. Physiol. 16, 398-403.

LeHNinger, A. L., 1970. Biochemistry. Worth, New York.

Lexander, K., Carlsson, R., Schalen, V., Simonsson, A., and Lundborg, T., 1970. Quantities and qualities of leaf protein concentrates from wild species and crop species grown under controlled conditions. Ann. appl. Biol. 66, 193-216.

Lyons, J. M. and RaISON, J. K., 1970. Oxidative activity of mitochondria isolated from plant tissues sensitive and resistant to chilling injury. Pl. Physiol. 45, 386-389.

LuCAs-Lenard, J. and Lipmann, F., 1971. Protein biosynthesis. A. Rev. Biochem. 40, 409-88. 
LÜtTGE, U., CRAM, W. J., and LATTES, G. G., 1971. The relationship of salt stimulated respiration to localized transport in carrot tissue. Z. Pfl. Physiol. 64, 418-26.

MACDONALD, I. R., 1968. Further evidence of oxygen diffusion as the determining factor in the relation between disk thickness and respiration of potato tissue. Pl. Physiol. 43, 274-80.

Macklon, A. E. S. and Higinbotham, N., 1970. Active and passive transport of potassium in cells of excised pea epicotyls. Xbid. 45, 133-38.

MANDELSTAM, J., 1960. The intracellular turn over of protein and nucleic acids and its role in biochemical differentiation. Bact. Rev. 24, 289-308.

MAUCK, J. and GLASER, L., 1970. Turnover of the cell wall of Bacillus subtilis W-23 during logarithmic growth. Biochem. biophys. Res. Commun. 39, 699-706.

MCCREE, K. J., 1970. An equation for the rate of respiration of white clover plants grown under controlled conditions. In Prediction and Measurement of Photosynthetic Productivity, pp. 221-9. Pudoc, Wageningen.

MilthORPE, T. L. and MoORBY, J., 1969. Vascular transport and its significance in plant growth. A. Rev. Pl. Physiol. 20, 117-38.

Moon, T. W. and Hochachk. 1971. Temperature and enzyme activity in poikilotherms. Biochem. $J$. $123,695-705$.

Morowitz, H. J., 1968. Energy Flow in Biology. Academic Press, London and New York.

MorozovskiI, V. V. and KABANOV, V. V., 1970. Efficiency of respiration in pea and glasswort under $\mathrm{NaCl}$ salinization of the substrate. Soviet Pl. Physiol. 17, 482-6.

NeTTER, H., 1969. Theoretical Biochemistry. Oliver and Boyd, Edinburgh.

Norris, T. E. and KocH, A. L., 1972. Effect of growth rate of the relative rates of synthesis of messenger, ribosomal and transfer RNA in E. coli.J. molec. Biol. 64, 633-49.

OAKs, A., WALlace, W., and Stevens, D., 1972. Synthesis and turnover of nitrate reductase in corn root. Pl. Physiol. 50, 649-54.

Pell, E. J. and Brennan, E., 1973. Changes in respiration, photosynthesis adenosine-5-triphosphate and total adenylate content of ozonated pinto bean foliage as they relate to symptom expression. Ibid. 51, 378-81.

PenNing De VRIEs, F. W. T., 1972. Respiration and growth. In Crop Processes in Controlled Environments, pp. 327-47. Ed. A. R. Rees, K. E. Cockshull, D. W. Hand and R. J. Hurd. Academic Press, London and New York.

-_- 1974. Use of assimilates in higher plants. In Photosynthesis and Productivity in Different Environments. Ed. J. Cooper. Cambridge University Press.

- Brunsting, A. H. M., and VAN LAAR, H. H., 1974. Products, requirements and efficiency of biosynthetic processes: a quantitative approach. $J$. theor. Biol. 45, 339-77.

Peterson, L. W., KLeINKopF, G. E., and HuFfaKer, R. C., 1973. Evidence for lack of turn over of ribulosedi-phosphate carboxylase in barley leaves. Pl. Physiol. 51, 1042-5.

PICKARD, W. F., 1972. Further observations on cytoplasmic streaming in Chara braunii. Can. J. Bot. 50, 703-11.

Pierce, W. S. and Higingotham, N., 1972. Compartments and fluxes of K, $\mathrm{Na}$ and $\mathrm{Cl}$ in Avena coleoptile cells. Pl. Physiol. 46, 666-73.

PINE, M. J., 1972. Turn over of intracellular proteins. A. Rev. Microbiol. 26, 103-26.

- 1973. Regulation of intracellular proteolysis in Escherichia coli. J. Bact. 115, 107-16.

PIRT, S. J., 1965. The maintenance energy of bacteria in growing cultures. Proc. R. Soc. B 163, 224-31.

Pitman, M. G., 1969. Simulation of $\mathrm{Cl}$ uptake by low-salt barley roots as a test of models of salt uptake. Pl. Physiol. 44, 1417-27.

PRINZ ZUR LIPPE, A., 1956. Ueber den Einflusz des vorangegangenen licht-dunkel Wechsels auf die $\mathrm{CO}_{2}{ }^{-}$ Ausscheidung der Primarblätter von Phaseolus multiflorus in anschliessender Dunkelheit. $Z, B o t$. $44,297-318$.

Racusen, D. and Foote, M., 1962. Protein turnover rate in bean leaf discs: Pl. Physiol. 37, $640-2$.

RainNIE, D. J. and BRAGG, P. D., 1973. The effect of iron deficiency on respiration and energy coupling in Escherichia coli. J. gen. Microbiol. 77, 339-49.

Romani, R. J. and OzelKoK, S., 1973. Survival of mitochondria in vitro. Pl. Physiol. 41, $702-7$.

Roth, R. M. and DAmpIER, C., 1972. Dependence of ribonucleic acid synthesis on continuous protein synthesis in yeasts. J. Bact. 109, 773-7.

Ryle, G. J. A., Brockington, N. R., Powell, C. E., and Cross, B., 1973. The measurement and prediction of organ growth in a uniculm barley. Ann. Bot. 37, 233-46.

SAdDler, H. D. W., 1970. Fluxes of sodium and potassium in Acetabularia. J. exp. Bot. 21, 605-16.

Samullov, F. D., Gordon, L. K., Petrov, V. E., and Bichurina, A. A., 1970. Influence of phosphorus nutrition on the energy effectiveness of respiration of plants under conditions of insufficient and excess moisture. Dokl. Akad. Nauk. SSSR, Bot. Sci. 193, 68-71. 
Schimke, R. T., 1969. On the roles of synthesis and degradation in regulation of enzyme levels in mammalian tissues. Current Topics in Cellular Regulation, Vol. 1, pp. 77-124. Academic Press, London and New York.

— and Doyle, D., 1970. Control of enzyme levels in animal tissue. A. Rev. Biochem. 39, 939-76.

Shlyk, A. A., 1970. Chlorophyll metabolism in green plants. Israel Program for Scientific Translations, Jerusalem.

Srekevitz, P., 1972. The turnover of proteins and the usage of information. $J$. theor. Biol. 37, 321-34.

STEER, B. T., 1973. Diurnal variations in photosynthetic products and nitrogen metabolism in expanding leaves. Pl. Physiol. 51, 744-8.

SteIn, W. D., 1967. The Movement of Molecules across Cell Membranes. Academic Press, London and New York.

Stouthamer, A. H., 1973. A theoretical study on ATP required for synthesis of microbial cell material. Antonie van Leeuwenhoek 39, 545-65.

- and BeTtENHAUSSEN, C., 1973. Utilization of energy for growth and maintenance in continuous and batch cultures. Biochem. biophys. Acta 301, 53-70.

Strogonov, B. P., 1964. Physiological basis of salt tolerance of plants. Israel Program for Scientific Translations, Jerusalem.

SutCliffe, J. F., 1973. The role of protein synthesis in ion transport. In Ion Transport in Plants, pp. $399-406$. Ed. W. P. Anderson. Academic Press, London.

Syretr, P. J., 1960. Einflüsse auszerer Faktoren auf die Atmung. 1B. The effect of minerals on plant respiration. Handbuch der Pflanzenphysiologie, Vol. 12.2, pp. 170-81. Ed. W. Ruhland, SpringerVerlag, Heidelberg.

TAmIYA, H. and Yamagutchi, S., 1933. Ueber die Aufbau- und die Erhaltungsatmung. Beitrage zur Atmungsphysiologie der Schimmelpilze. III. Acta Phytochim. 7, 43-64.

TANAKA, A., 1972. Efficiency of respiration. Rice Breeding, Int. Rice Research Inst., pp. 483-98. Los Banos, Philippines.

Tanner, W., Grünes, R., and Kandler, O., 1970. Spezifität und Turnover des induzierbaren Hexose Aufnahmesystems von Chlorella. Z. Pf. Physiol. 62, 376-86.

Thorhaug, A., 1971. Temperature effects on Valonia bioelectric potential. Biochem. biophys. Acta 225 , 151-8.

Thornley, J. H. M. and Hesketh, J. D., 1972. Growth and respiration of cotton bolls. J. appl. Ecol. 9, 315-7.

Travis, R. L., JoRdAN, W. R., and HufFAKER, R. C., 1969. Evidence for an inactivating system of nitrate reductase in Hordeum vulgare L. during darkness that requires protein synthesis. Pl. Physiol. 44, 1150-6.

TREWAVAS, A., 1970. The turn over of nucleic acids in Lemna minor. Ibid. 45, 742-51.

- 1972. Control of the protein turnover rates in Lemna minor. Ibid. 49, 47-51.

VREDENBERG, W. J., 1972. A method for measuring the kinetics of energy dependent changes in the electrical membrane resistance of metabolizing plant cells. Biochem. biophys. Acta 274, 505-14.

Waisel, Y., 1972. Biology of Halophytes. Academic Press, London and New York.

Watson, T. G., 1970. Effect of sodium chloride on steady state growth and metabolism of Saccharomyces cerevisiae. J. gen. Microbiol. 64, 91-9.

Went, F. W., 1957. The Experimental Control of Plant Growth. Chronica Botanica, Waltham, Massachusetts.

Wit, C. T. De, Brouwer, R., and Penning De VRies, F. W. T., 1970. The simulation of photosynthetic systems. In Prediction and Measurement of Photosynthetic Productivity, pp. 47-69. Pudoc, Wageningen.

Yамамото, A., 1933. Ueber den Einfluss einiger Gifte und der Temperatur auf den Ausnutzungsgrad der Atmungsenergie beim Wachstum des Schimmelpilzes. Acta Phytochim. 7, 65-92.

Yoda, K., Shinozaki, K., Ogawa, H., Hozumr, K., and Kira, T., 1965. Estimation of the total amount of respiration in woody organs of trees and forest communities. .J. Biol. Osaka City Univ. 16, 15-26.

Zaitseva, M. G., Titova, Z. V., and Sarsenbaev, B., 1970. Properties of mitochondria in roots of wheat grown under different conditions of phosphate nutrition. Soviet Pl. Physiol. 17, 819-26.

ZuCker, M., 1972. Light and enzymes. A. Rev. Pl. Physiol. 23, 133-56. 